\title{
Evaluation of Subcutaneous Adipose Tissue in the Thigh and Calf Region for Subcutaneous Injection by Computed Tomography
}

\author{
Uyluk ve Baldar Bölgesindeki Deri Altı Yăg Dokusunun Subkutan Enjeksiyona Uygunluğunun \\ Bilgisayarl Tomografi ile Değerlendirilmesi
}

\section{Eren İSMAİLOĞLU1*, Elif Günay İSMAİLOĞLU²*}

\author{
${ }^{1}$ İzmir Bakırçay University, Faculty of Medicine, Department of Radiology, İzmir, Turkey \\ 2̇̇zmir Bakırçay University, Faculty of Health Sciences, Department of Nursing, İzmir, Turkey
}

\begin{abstract}
The most commonly used areas in the lower extremity in subcutaneous injection applications are anterior and lateral surface of the thigh. The calf region, which is an alternative to these areas, is located in the lateral region of the gastrocnemius muscle. The aim of the study is to retrospectively evaluate of suitability of thigh and calf site subcutaneous adipose tissue thickness for subcutaneous injection through computed tomography sections. The sample of this descriptive study consisted of 140 adult patients over the age of 18 who underwent Contrast-Enhanced Lower Extremite Computed Tomography Angiography between March 2020 and March 2021. Subcutaneous tissue thicknesses of the anterior thigh, lateral thigh, and calf injection site of the subjects were measured by a specialist radiologist using computed tomography sections. As a result of the study, a comparison of subcutaneous tissue thickness in the thigh and calf was achieved according to gender and body mass index. The mean subcutaneous tissue thickness of the patients was $13.64 \pm 6.85 \mathrm{~mm}$ on the anterior thigh, $8.82 \pm 7.21 \mathrm{~mm}$ on the lateral side of the thigh, and $6.15 \pm 3.12 \mathrm{~mm}$ in the calf area. It was found that there was a significant difference between subcutaneous tissue thicknesses according to their gender and body mass index. Subcutaneous tissue thickness on the anterior thigh was thicker than the lateral thigh and the calf injection site. Subcutaneous tissue thickness in females was greater than in males. Subcutaneous tissue thickness in the calf region was thicker than $4 \mathrm{~mm}$ in $77.1 \%, 8 \mathrm{~mm}$ in $19.3 \%$ and $12 \mathrm{~mm}$ in $12.3 \%$.
\end{abstract}

Keywords: Calf region, Computed tomography, Subcutaneus injection, Subcutaneus tissue, Needle length.

Öz: Subkutan enjeksiyon uygulamalarında alt extremitede en fazla kullanılan bölgeler uyluk ön ve yan yüzüdür. Literatürde geçen ve pratikte kullanılan bu bölgelere alternatif olan baldır bölgesi gastroknemius kasının yan bölgesinde yer almaktadır. Araştırmanın amacı, bireylerde uyluk ve baldır bölgesi deri altı yağ dokusu kalınlığının subkutan enjeksiyona uygunluğunun bilgisayarlı tomografi kesitleri üzerinden ölçülerek retrospektif değerlendirilmesidir. Tanımlayıcı tipte olan araştırmanın örneklemini Mart 2020 - Mart 2021 tarihleri arasında Kontrastlı Alt Extremite Bilgisayarlı Tomografi Anjiografi çekilen 18 yaş üzeri 140 yetişkin birey oluşturdu. Bireylerin uyluk ön yüz, uyluk yan yüz ve baldır bölgesindeki subkutan doku kalınlıkları bir uzman radyolog tarafindan bilgisayarlı tomografi kesitleri üzerinden ölçüldü. Araştırma sonucunda cinsiyet ve beden kitle indeksine göre uyluk ve baldır bölgesindeki subkutan doku kalınlığının karşılaştırılması sağlandı. Bireylerin subkutan doku kalınlığı ortalamaları uyluk ön yüzde 13,64£6,85 uyluk yan yüzde $8,82 \pm 7,21$ ve baldır bölgesinde $6,15 \pm 3,12 \mathrm{~mm}$ olarak bulundu. Bireylerin cinsiyet ve beden kitle indeksine göre subkutan doku kalınlıkları arasında anlamlı fark olduğu saptandı. Uyluğun ön yüzündeki subkutan doku kalınlığ1 uyluğun yan yüzü ve baldır bölgesine göre daha kalındı. Kadın bireylerde tüm enjeksiyon bölgesindeki subkutan doku kalınlığı erkeklerden daha fazlaydı. Baldır bölgesinde subkutan doku kalınlıkları bireylerin \% 77,1 'inde 4 mm'den, \%19,3'ünde 8 mm'den ve \%12,3'ünde 12 mm'den daha kalındı.

Anahtar Kelimeler: Baldır bölgesi, Bilgisayarlı tomografi, İğne uzunluğu, Subkutan enjeksiyon, Subkutan doku

${ }^{*}$ Corresponding author : Elif Günay ISMAİLĞLU e-mail : elif.ismailoglu@bakircay.edu.tr

Geliş tarihi / Received : 13.07.2021 Kabul tarihi / Accepted: 12.08.2021 


\section{Introduction}

Subcutaneous injection, which is one of the parenteral drug administration types, is the administration of the drug to the fat layer located under the dermis and above the muscle layer. Since the subcutaneous fat layer is not rich in blood vessels, the drug is absorbed more slowly from the muscle tissue. In subcutaneous injection, only small doses (0.5-1-2 ml) of water-soluble drugs should be administered (Potter et al. 2017; Berman et al. 2016; Turan et al. 2019). Otherwise, the excess amount of drug causes pressure on the nerve endings (Zijlstra et al. 2018; Turan et al. 2019). The most commonly used areas for subcutaneous injection are the outer aspect of the upper arm, the abdomen and the anterior and lateral aspect of the thigh (Potter et al. 2017; Berman et al. 2016). In particular, individuals who use self-injection prefer these regions. Although it is not used much in practice, the lower aspect of the scapula and the upper aspects of the dorsogluteal region on the back are also included in the literature for subcutaneous injection. Absorption is fastest in the abdominal region, moderate in the arms, and slower on the anterior aspect of the thigh (Potter et al. 2017; Berman et al. 2016, Dalkıran 2014).

Insulin, heparin, analgesics, drugs used in allergy treatment and mixed vaccines in children are administered by subcutaneous route (Potter et al. 2017; Berman et al. 2016). Patients who are constantly administered insulin or heparin experience discomfort and pain due to repeated injections. As a result of frequent injections in the same area and accumulation of the drug in the subcutaneous tissue (ST), sterile abscesses are formed under the skin in the form of hardened, painful lumps and may lead to lipohypertrophy and lipoatrophy. In such cases, patients are faced with the risk of skipping the injection dose or interrupting the treatment. In order to eliminate these disadvantages, patients who are constantly administered insulin or heparin should rotate between regions in injection practices (Dalkıran 2014; Pozzuoli et al. 2018). A study was found in the literature that reported that the calf region is suitable for the subcutaneous injection region which can be used as an alternative to the subcutaneous injection regions that are in practice. The study stated that the calf region is important because it is easy to access and adds extra injection sites to the rotation (Torun and Mutluay 2017). The calf region is located in the lateral region of the gastrocnemius muscle. The study which investigated the suitability of the region for subcutaneous injection in Turkey utilized a skinfold caliper to measure the skinfold thickness in the calf region and found that the subcutaneous injections made with $8 \mathrm{~mm}$ needle in $86.3 \%$ of the individuals were applicable to the region (Torun and Mutluay 2017). In addition, the above mentioned study proposed evaluating the region with radiological methods. Therefore, the present study aimed to measure the thickness of the subcutaneous adipose tissue in the lower extremity subcutaneous injection sites (thigh and calf regions) through Computed Tomography (CT) sections. The study set out to retrospectively evaluate the suitability of thigh and calf region ST thickness for subcutaneous injection through CT sections. Thus, the study aimed to;

- reveal the suitability of the thigh and calf regions for subcutaneous injection,

- compare ST thickness in thigh and calf regions based on gender and body mass index

\section{Material and Method}

The population of the retrospective descriptive study consisted of adult individuals over the age of 18 who underwent Contrast-Enhanced Lower Extremity CT Angiography between March 2020 and March 2021 in a training and research hospital in Izmir $(\mathrm{N}=400)$. While determining the sample of the research, stratified sampling method was chosen among the probabilistic sampling methods to be unbiased and represent the universe. Individuals were stratified by age and gender to 
represent the universe. The targeted sample size was determined as 140 for $95 \%$ power as a result of the sample size calculation. The research was completed with 140 participants. CT images including the distance from the umbilical level to the distal part of the foot were included in the study. Individuals with an anatomical defect in the thigh and calf regions, with any fractures and open wounds and those with flexion in the knee joint and external rotation in the calf region sufficient to cause compression were excluded from the study.

A case report form was used to collect and record research data on the age, sex, height and weight of the individuals and the ST thicknesses obtained by $\mathrm{CT}$ measurement in the thigh and calf injection sites.

\section{Data Collection}

A 128-slice CT device (Optima CT 660, GE Healthcare System, Milwaukee, USA) was used to obtain Contrast-Enhanced Lower Extremity CT Angiography images of the participating individuals. In the study, Contrast-Enhanced Lower Extremity CT Angiography examinations were evaluated retrospectively by a radiologist.

The following measurements were taken to collect the data in the study.

1. The age, gender, height and weight values of the patients were obtained from the hospital database.

2. Subcutaneous injection points in the thigh and calf regions were detected on CT images using the method mentioned in the literature. Coronal and sagittal plane reformat images were used to detect injection sites on tomography sections. The region on the lateral aspect of the gastrocnemius muscle (approximately $10 \mathrm{~cm}$ below the lateral aspect of the knee) was used to determine the calf region (Torun and Mutluay 2017). The anterior (1/3 distal part of the rectus femoris muscle) and the lateral aspect $(1 / 3$ distal part of the vastus lateralis muscle) of the thigh were used to determine the thigh region (Potter et al. 2017; Berman et al.
2016). Measurement points were determined on the reference lines passing through the center of the muscles in the thigh.

3. After the points were determined, ST thicknesses $(\mathrm{mm})$ in the calf and thigh regions were measured on axial plan CT images with a section thickness of $0.625 \mathrm{~mm}$. All measurements were taken from the left leg (Fig. 1,2).

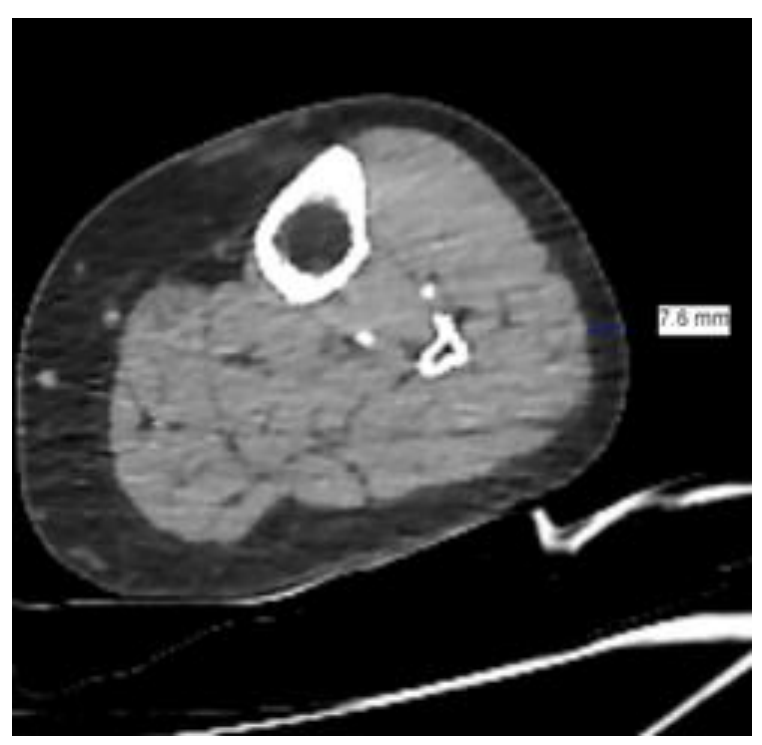

Figure 1. Subcutaneous tissue thickness of the calf region.

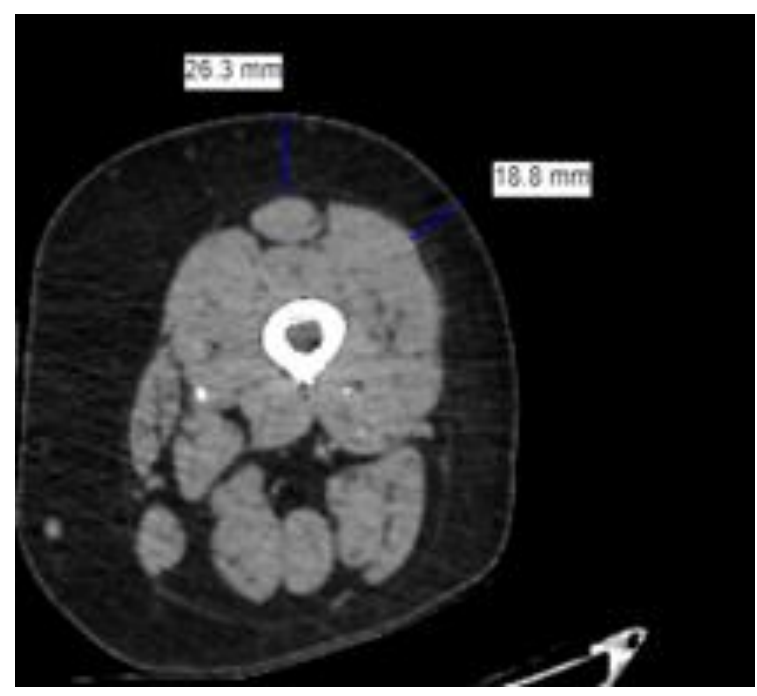

Figure 2. Subcutaneous tissue thickness of the anterior (A) and lateral (B) sides of the thigh 


\section{Statistical analysis}

Data were analyzed by using The Package for Social Sciences (SPSS) 20 package program. The number, percentile, mean and standard deviation of the data regarding the physical measurements of the individuals were presented. The $t$-test was used to analyze the difference between the ST thicknesses in the thigh and calf regions based on gender while the analysis of variance was used to analyze the difference between the ST thicknesses in the thigh and calf regions based on body mass index. Statistical significance level was accepted to be $\mathrm{p}<0.05$.

\section{Ethical Approach}

Before the study, permission was obtained from the ethics committee of non-interventional clinical studies (dated 01/04/2020, decision no 239, research number 220).

\section{Results}

Table 1. Descriptive Characteristics of Individuals
Table 1 presents the descriptive characteristics of the individuals included in the study. The mean age

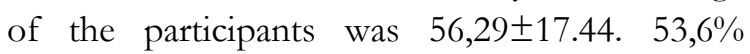
$(\mathrm{n}=75)$ were male, $21,4 \% \quad(\mathrm{n}=30)$ had normal weight, $52,1 \%$ were slightly overweight $(\mathrm{n}=73)$ and $26,4 \%$ were overweight. $(n=37)$ was found. Participants' mean body mass index was $27,98 \pm 3.84$.

Participants' mean ST was $13,64 \pm 6,85,8,82 \pm 7,21$ and $6,15 \pm 3,12 \mathrm{~mm}$, respectively in the thigh anterior, thigh lateral and calf injection regions $(\mathrm{F}=55,66 ; \mathrm{df}=2 ; \mathrm{p}=000)$ (Table 2). The post hoc analysis determined that the ST thickness in the anterior thigh was thicker than it was in the lateral thigh $(p<0.001)$ and in the calf region $(p<0.001)$ and the ST thickness in the lateral thigh was thicker than the calf region $(\mathrm{p}=0.000)$.

The mean ST thickness according to the gender was $18,24 \pm 7,07 \mathrm{~mm}$ in females and $9,64 \pm 3,19 \mathrm{~mm}$ in males on the anterior thigh; $13,46 \pm 8,17 \mathrm{~mm}$ in females, $4,8 \pm 2,16 \mathrm{~mm}$ in males on the lateral thigh and $8,04 \pm 3,5 \mathrm{~mm}$ in females and $4,5 \pm 1,37 \mathrm{~mm}$ in males in the calf region. The analysis showed that the $\mathrm{ST}$ in the anterior thigh, lateral thigh and calf injection regions was thicker in females (Table 3).

\begin{tabular}{|c|c|c|}
\hline & n & $\%$ \\
\hline Age (M $\pm S D)$ (Min-Max) & $56,29 \pm 17,44(18-88)$ & \\
\hline \multicolumn{3}{|l|}{ Gender } \\
\hline Female & 65 & 46,4 \\
\hline Men & 75 & 53,6 \\
\hline Body mass index (ort $\pm S S)$ (Min-Max) & $27,98 \pm 3,84(20,83-38,46)$ & \\
\hline 20-24,99 (normal weight) & 30 & 21,4 \\
\hline $25-29.9$ (slightly overweight) & 73 & 52,1 \\
\hline 30-39.9 (overweight) & 37 & 26,4 \\
\hline Total & 140 & 100 \\
\hline
\end{tabular}

$\mathrm{M}=$ Mean; $\mathrm{SD}=$ Standard deviation;

Table 2. Subcutaneous Tissue Thicknesses at the Thigh and Calf Injection Sites of Individuals

\begin{tabular}{lcccccc}
\hline & \multicolumn{2}{c}{ ST thickness $(\mathrm{n}=140)$} & \multicolumn{3}{c}{ Statistical analysis } \\
Regions & Mean \pm SD $(\mathrm{mm})$ & Min-Max & F & df & p \\
\hline
\end{tabular}




\begin{tabular}{lccccc}
\hline Anterior thigh & $13,65 \pm 6,85$ & $3,7-44$ & & & \\
Lateral thigh & $8,82 \pm 7,21$ & $2,1-45,2$ & 55,66 & 2 & 0,000 \\
Calf & $6,15 \pm 3,12$ & $2,3-19,5$ & & & \\
\hline
\end{tabular}

ST= Subcutaneous tissue; $\mathrm{SD}=$ Standard deviation; F= One Way Anova

Table 3. Average Subcutaneous Tissue Thickness in Thigh and Calf Regions by Gender and Body Mass Index

\begin{tabular}{|c|c|c|c|c|}
\hline & $\mathrm{n}$ & $\begin{array}{l}\text { Anterior thigh } \\
\text { ST thickness } \\
(\mathrm{M} \pm \mathrm{SD})\end{array}$ & $\begin{array}{l}\text { Lateral thigh } \\
\text { ST thickness } \\
(\mathrm{M} \pm \mathrm{SD})\end{array}$ & $\begin{array}{c}\text { Calf } \\
\text { ST thickness } \\
(\mathrm{M} \pm \mathrm{SD})\end{array}$ \\
\hline \multicolumn{5}{|l|}{ Gender } \\
\hline Female & 65 & $18,24 \pm 7,07$ & $13,46 \pm 8,17$ & $8,04 \pm 3,5$ \\
\hline Men & 75 & $\begin{array}{c}9,64 \pm 3,19 \\
\mathbf{t}=\mathbf{9 , 0 4} \mathrm{p}=\mathbf{. 0 0 0}\end{array}$ & $\begin{array}{c}4,8 \pm 2,16 \\
t=8,3 p=.000\end{array}$ & $\begin{array}{c}4,5 \pm 1,37 \\
\mathrm{t}=\mathbf{7 , 6 6} \mathrm{p}=\mathbf{. 0 0 0}\end{array}$ \\
\hline \multicolumn{5}{|l|}{ Body mass index $\left(\mathrm{kg} / \mathrm{m}^{2}\right)$} \\
\hline 20-24,99 (normal weight) & 30 & $8,67 \pm 3,38$ & $4,4 \pm 2,65$ & $4,39 \pm 2,2$ \\
\hline $25-29.9$ (slightly overweight) & 73 & $12,29 \pm 5$ & $7,12 \pm 4,76$ & $5,65 \pm 2,13$ \\
\hline 30-39.9 (overweight) & 37 & $\begin{array}{c}20,31 \pm 7,22 \\
F=\mathbf{4 3 , 1 4 1} \mathbf{d f}=\mathbf{2} \\
\mathrm{p}=\mathbf{0 0 0}\end{array}$ & $\begin{array}{c}15,75 \pm 8,83 \\
\mathbf{F}=\mathbf{3 8 , 0 0 4} \mathbf{d f}=\mathbf{2} \\
\mathbf{p}=\mathbf{0 0 0}\end{array}$ & $\begin{array}{c}8,56 \pm 3,96 \\
\mathbf{F}=\mathbf{2 1 , 6 4} \mathbf{d f}=\mathbf{2} \\
\mathrm{p}=\mathbf{0 0 0 0}\end{array}$ \\
\hline
\end{tabular}

$\mathrm{ST}=$ Subcutaneous tissue; $\mathrm{M}=$ Mean; $\mathrm{SD}=$ Standard deviation; $\mathrm{t}=$ Independent sample $\mathrm{t}$ test; $\mathrm{F}=$ Oneway Anova

The mean ST thickness according to the body mass index was $8,67 \pm 3,38 \mathrm{~mm}$ on the anterior thigh in normal-weight individuals, $12,29 \pm 5 \mathrm{~mm}$ on the anterior thigh in slightly overweight individuals and $20,31 \pm 7,22 \mathrm{~mm}$ on the anterior thigh in overweight individuals. On the lateral thigh, ST thickness was $4,4 \pm 2,65 \mathrm{~mm}$ in normalweight individuals, $7,12 \pm 4,76 \mathrm{~mm}$ in slightly overweight individuals and $15,75 \pm 8,83 \mathrm{~mm}$ in overweight individuals. In the calf region, ST thickness was $4,39 \pm 2,2 \mathrm{~mm}$ in normal-weight individuals, $5,65 \pm 2,13 \mathrm{~mm}$ in slightly overweight individuals and $8,56 \pm 3,96 \mathrm{~mm}$ in overweight individuals. According to body mass index, there was a significant difference between ST thicknesses in anterior thigh, lateral thigh and calf injection regions (Table 3).

ST on the anterior thigh was thicker than $4 \mathrm{~mm}$ in $99,3 \%$ of the individuals ( $\mathrm{n}=139)$, thicker than 8 $\mathrm{mm}$ in $80,7 \%$ of the individuals $(\mathrm{n}=113)$ and thicker than $12 \mathrm{~mm}$ in $53,6 \%$ of the individuals $(n=75)$. ST on the lateral thigh was thicker than 4 $\mathrm{mm}$ in $74,3 \%(\mathrm{n}=104)$ of the individuals, thicker than $8 \mathrm{~mm}$ in 39,3\% of the individuals $(\mathrm{n}=55)$ and thicker than $12 \mathrm{~mm}$ in $23,6 \%$ of the individuals $(\mathrm{n}=33)$. ST on the calf region was thicker than 4 $\mathrm{mm}$ in $77,1 \%$ of the individuals $(\mathrm{n}=108)$, thicker than $8 \mathrm{~mm}$ in $19,3 \%$ of the individuals $(\mathrm{n}=27)$ and thicker than $12 \mathrm{~mm}$ in $12,3 \%$ of the individuals $(n=8)$. In addition, Table 4 presents the distribution of ST thicknesses greater than $4 \mathrm{~mm}$, $8 \mathrm{~mm}$ and $12 \mathrm{~mm}$ in all regions by gender.

\section{Discussion}

In subcutaneous injection, the drug is usually administered to the abdomen, hips, arms and legs with rotation. The anterior and lateral aspects of the thigh on the leg are theoretically acknowledged and used in practice (Potter et al. 2017; Berman et al. 2016). In addition, a study reported that the lateral aspect of the calf may used as a subcutaneous injection site (Torun and Mutluay 2017). Therefore, this study aimed to evaluate the suitability adult individuals' thigh and calf regions for subcutaneous injection with the help of CT. For this purpose, thigh and calf injection sites were 
measured for ST thickness with CT by a specialist radiologist. The mean ST thickness values in the anterior thigh, lateral thigh and calf injection regions obtained from the measurements were $13,64 \pm 6,85, \quad 8,82 \pm 7,21$ and $6,15 \pm 3,12 \mathrm{~mm}$ respectively. Similarly, the mean ST thickness in the thigh region was calculated as $10.4 \mathrm{~mm}$ by Gibney et al. (2010), as $7.92 \mathrm{~mm}$ by Akkuş et al. (2012), as $12.4 \pm 4.1 \mathrm{~mm}$ by Dalkıran (2014) and as $11.2 \mathrm{~mm}$ in by Akyer (2014). In the present study, ST on the anterior thigh was found to be thicker compared to the lateral thigh and the calf region. The study conducted by Torun and Mutluay (2017) also reported that ST thickness on the

Table 4. ST thicknesses greater than $4 \mathrm{~mm}, 8 \mathrm{~mm}$ and $12 \mathrm{~mm}$ by gender

\begin{tabular}{|c|c|c|c|c|c|c|}
\hline \multirow[t]{2}{*}{ ST thickness } & \multicolumn{2}{|c|}{ Female $(n=65)$} & \multicolumn{2}{|c|}{ Male $(n=75)$} & \multicolumn{2}{|c|}{ Total $(n=140)$} \\
\hline & $\mathbf{n}$ & $\%$ & $\mathbf{n}$ & $\%$ & $\mathbf{n}$ & $\%$ \\
\hline \multicolumn{7}{|l|}{ Anterior thigh } \\
\hline$>4 \mathrm{~mm}$ & 65 & 100 & 74 & 98,7 & 139 & 99,3 \\
\hline$>8 \mathrm{~mm}$ & 62 & 95,4 & 51 & 68 & 113 & 80,7 \\
\hline$>12 \mathrm{~mm}$ & 42 & 64,6 & 33 & 44 & 75 & 53,6 \\
\hline \multicolumn{7}{|l|}{ Lateral thigh } \\
\hline$>4 \mathrm{~mm}$ & 61 & 92,8 & 43 & 57,3 & 104 & 74,3 \\
\hline$>8 \mathrm{~mm}$ & 48 & 73,8 & 7 & 9,3 & 55 & 39,3 \\
\hline$>12 \mathrm{~mm}$ & 32 & 49,2 & 1 & 1,3 & 33 & 23,6 \\
\hline \multicolumn{7}{|l|}{ Calf } \\
\hline$>4 \mathrm{~mm}$ & 60 & 92,3 & 48 & 64 & 108 & 77,1 \\
\hline$>8 \mathrm{~mm}$ & 26 & 40 & 1 & 1,3 & 27 & 19,3 \\
\hline$>12 \mathrm{~mm}$ & 8 & 12,3 & - & - & 8 & 12,3 \\
\hline
\end{tabular}

$\mathrm{ST}=$ Subcutaneous tissue

The subcutaneous injections, based on injecting the drug into the subcutaneous adipose tissue, require needles that must pass through the dermis and reach the subcutaneous adipose tissue (Potter et al. 2017; Berman et al. 2016). Since the blood flow in the subcutaneous adipose tissue is slower than the muscle layer, the administered drug is absorbed at a more controllable rate (Lo Presti et al. 2012). ST thickness is one of the parameters that determines the suitability of the regions for subcutaneous injection. The distance from the skin surface to the muscle fascia largely depends on ST thickness (Hirsch and Strauss 2019). In the present study, ST thickness of the anterior thigh, anterior thigh was quantitatively higher than that of the lateral thigh. The ST thickness in the calf region was found to range from $2.3 \mathrm{~mm}$ to 19.5 mm. In their study, Akyer et al. (2014) concluded that the mean ST thickness in the calf region was $8,3 \pm 4,7 \mathrm{~mm}$. As a matter of fact, subcutaneous adipose layer in the calf region is thinner than the anterior and lateral aspects of the thigh. Similar results were found in different studies as well (Akyer et al. 2014; Pe'rez-Chirinos Buxade et al. 2018). Compared to other injection sites in the leg, the calf region is thinner but short needles can be used in this region.

6

To cite this article: ISSMAILOĞLU E, ISSMAILOĞLU EG. (2021). Evaluation of Subcutaneous Adipose Tissue in the Thigh and Calf Region for Subcutaneous Injection by Computed Tomography. MAKU J. Health Sci. Inst., 9(2), 1-9

lateral thigh and calf region was measured to evaluate the suitability of these regions for subcutaneous injection. Needle length is one of the main factors affecting the access to the subcutaneous layer in subcutaneous injection (Hirsch and Strauss 2019). Needle lengths used in subcutaneous injection vary from $4 \mathrm{~mm}$ to $15 \mathrm{~mm}$. According to the measurement values obtained in the study, it was found that the calf region was suitable for a $4 \mathrm{~mm}$ needle in $77,1 \%$ of individuals, for an $8 \mathrm{~mm}$ needle in 19,3\% of individuals and for a $12 \mathrm{~mm}$ needle in $12,3 \%$ of individuals. As a result, it can be argued that the calf region is more suitable for subcutaneous injection with a short 
needle. For the 4, 8 and $12 \mathrm{~mm}$ needles, these rates were found to be $99,3 \%, 80,7 \%$ and $53,6 \%$ on the anterior aspect of the thigh and 74,3\%,39,3\% and $23,6 \%$ on the lateral aspect of the thigh, respectively. As can be seen, the chance of the needle reaching the subcutaneous tissue decreases in all regions as the needle length increases. This will increase the risk of the needle reaching the muscle tissue. These results are supported by the literature. In the literature, it is recommended to use short needles in subcutaneous injections so that the drug is not administered intramuscularly (Hirsch et al. 2014; Bergenstal et al. 2015; Spollett et al. 2016; Misnikova et al. 2017; Guo and Wang 2017; Hirsch and Strauss 2019).

It is now widely accepted that $4 \mathrm{~mm}$ pen needles (pen injectors) are suitable for all patients, whether they are adults or children, thin or obese, males or females (Hirsch and Strauss 2019). The study conducted by Tubiana rufi et alç (2009) concluded that $84 \%$ of the injections made using $12,7 \mathrm{~mm}$ needles in children were made into the muscle. It is also known that the use of short needle tips (4$5 \mathrm{~mm}$.) reduces pain and is more effective in controlling blood sugar (Diggle 2014; Hirsch and Strauss 2019; Turan et al. 2019).

Subcutaneous adipose tissue thickness varies depending on BMI, gender and injection site. When the mean ST thicknesses in the thigh and calf injection regions were analyzed by gender, it was found that ST thickness was higher in females in all measurement regions. Torun and Mutluay (2017) reported that ST thickness was higher in females compare to males in all regions where subcutaneous injection was performed. Postpubertal females have an average of $5 \mathrm{~mm}$ more subcutaneous adipose thickness compared to males (Hirsch et al. 2014; Hirsch and Strauss 2019). The findings of the present study also support the results of other studies (Gibney et al. 2010; Torun and Mutluay 2017). However, Dalkıran's (2014) study which used ultrasound for measurements confirmed that gender had no effect on the subcutaneous adipose tissue. Torun and Mutluay (2017) reported the ST thickness values as follows: $29,91 \mathrm{~mm}$ in females and 16,22 $\mathrm{mm}$ in males for anterior thigh; $29,08 \mathrm{~mm}$ for females and 13,88 $\mathrm{mm}$ for males for lateral thigh and $23,72 \mathrm{~mm}$ in females and $12,09 \mathrm{~mm}$ in males for the calf region. In this study, it is noteworthy that the mean thickness values were higher for all regions (Table 4).

Torun and Mutluay measured the subcutaneous tissue thickness with skinfold, while the present study subcutaneous tissue thickness was measured with CT. CT has the advantage of clearly distinguishing adipose tissue from other tissues and measuring directly from cross-sectional images (Pe'rez-Chirinos Buxade et al. 2018; Fraiz et al. 2020). In their study, Akyer et al. (2014) measured the ST thickness in the calf region as $11.1 \mathrm{~mm}$ for females with US, while ST thickness was found to be $22.2 \mathrm{~mm}$ with skinfold; the ST thickness in the calf region was $5.5 \mathrm{~mm}$ for males with US and $12.6 \mathrm{~mm}$ with skinfold. The analysis demonstrated this difference as significant. The study determined that there was a significant difference not only in the calf region but also in the thigh region and ST thickness values were always higher with the skinfold method. Similar studies also showed that all variables were higher in skinfold measurement (Wagner et al. 2016; Pe'rez-Chirinos Buxade et al. 2018). This difference is explained by the fact that while other methods directly measure the subcutaneous adipose thickness, the measurements performed with the skinfold caliper take subcutaneous adipose tissue and double-layer skin thickness into consideration as well (Akyer et al. 2014; Pe'rezChirinos Buxade et al. 2018).

Subcutaneous adipose tissue thicknesses vary in the thigh and calf regions according to the body mass index. While the mean ST thickness of overweight individuals was found to be significantly higher than that of slightly overweight and normal-weight individuals on the anterior thigh, the mean ST thickness of overweight individuals on the lateral aspect of the thigh and in the calf region were found to be significantly higher compared to individuals with normal- 
weight. Accordingly, it can be concluded that as BMI increases, the thickness of subcutaneous adipose tissue increases. this result is consistent with other studies (Dalkıran 2014; Hirsch et al. 2019). As a result, it was observed that BMI had an effect on skin thickness and subcutaneous adipose tissue.

It was found that the calf region was suitable for subcutaneous injection when $4 \mathrm{~mm}$ needles were used in $92,3 \%$ of the females and $64 \%$ of the males. However, this ratio was found to be decreased as the needle length increased. When an $8 \mathrm{~mm}$ needle was used, the calf region was suitable for subcutaneous injection in $40 \%$ of the females and only $1,3 \%$ of the males. This shows that when a needle longer than $8 \mathrm{~mm}$ is used in injection to the calf region, the drug will reach the muscle tissue, not the subcutaneous adipose tissue, especially in males. This result also supports the literature (Turan et al. 2019). Torun and Mutluay also reported that injection to the calf region was found appropriate in $75,3 \%$ of the males when an 8 -mm needle was used and in $27,2 \%$ of the males when a $15-\mathrm{mm}$ needle was used. This result can be explained by the fact that males have less subcutaneous adipose tissue in the calf region and thicker muscle layer compared to females. For this reason, the needle tip longer than $8 \mathrm{~mm}$, especially in thin males or males with normal weight causes the drug to be administered to the muscle (Turan et al. 2019). Considering that $126 \mathrm{~mm}$ needles are used in heparin injections, it is concluded that this region is not suitable for females $(12,3 \%)$ or males $(0 \%)$.

\section{Conclusion}

ST thickness on the anterior aspect of the thigh was higher compared to the lateral aspect of the thigh and the calf injection site. ST thickness at the entire injection site higher in females compared to males. ST thickness in the calf region was higher than $4 \mathrm{~mm}$ in $77,1 \%$ of the individuals, higher than $8 \mathrm{~mm}$ in $19,3 \%$ of the individuals and higher than $12 \mathrm{~mm}$ in $12,3 \%$ of the individuals.
Akkus, O., Oguz, A., Uzunlulu, M., Kizilgul, M., 2012. Evaluation of skin and subcutaneous adipose tissue thickness for optimal insulin injection. Journal of Diabetes \& Metabolism 3(8), 1-5.

Akyer, Ş. P., Adigüzel, E., Sabir, N., Akdoğan, I., Yilmaz, B., Yonguç, G. N., 2014. Comparison of ultrasonography and skinfold measurements of subcutaneous fat thickness in the evaluation of body composition. Anatomy 8(1), 1-8.

Bergenstal, R.M., Strock, E.S., Peremislov, D., Gibney, M.A., Parvu, V., Hirsch, L.J., 2015. Safety and efficacy of insulin therapy delivered via a $4 \mathrm{~mm}$ pen needle in obese patients with diabetes. Mayo Clinic Proceedings 90(3), 329-338.

Berman, A.T., Snyder, C., Frandsen, G., Kozier, Erb's., 2016. Fundamentals of Nursing, UK: Global Edition. Pearson Education p.791-796.

Dalkıran, Ş., 2014. Subkutan insulin enjeksiyonu uygulamasında deri kalınlığı, subkutan yağ dokusu ve iğne boyu seçiminin metabolik kontrol üzerine etkisi. Akdeniz Üniversitesi Sağlık Bilimleri Enstitüsü İç Hastalıkları Anabilim Dalı, Yayınlanmamış Yüksek Lisans Tezi.

Diggle, D. 2014. Are you FIT for purpose? The importance of getting injection technique right. J Diabetes Nurs. 18, 50.

Fraiz, G.M., Gallo, L.H., Rabito, E.I., Gomes, A.R.S., Schieferdecker, M.E.M. (2020). Relationship between muscle thickness and calf circumference in healthy older women. Archives of Gerontology and Geriatrics, 86, 103942.

Gibney, M.A., Arce, C.H., Byron, K.J., Hirsch, L.J., 2010. Skin and subcutaneous adipose layer thickness in adults with diabetes at sites used for insulin injections: implications for needle length recommendations. Current Medical Research and Opinion 26(6), 15191530.

Guo, X., Wang, W., 2017. Challenges and recent advances in the subcutaneous delivery of insulin. Expert Opinion on Drug Delivery 14(6), 727-734.

Hirsch, L., Byron, K., Gibney, M., 2014. Intramuscular risk at insulin injection sitesmeasurement of the distance from skin to muscle and rationale for shorter-length needles for subcutaneous insulin therapy. Diabetes Technology \& Therapeutics $16,867-73$.

Hirsch, L.J., Strauss, K.W., 2019. The injection technique factor: what you don't know or teach can make a difference. Clinical Diabetes 37(3), 227-233.

\section{References}


Misnikova, I.V., Gubkina, V.A., Lakeeva, T.S., Dreval, A.V., 2017. A randomized controlled trial to assess the impact of proper insulin injection technique training on glycemic control. Diabetes Therapy 8(6), 1309-1318.

Perez-Chirinos Buxade, C., Solà-Perez, T., Castizo-Olier, J., Carrasco-Marginet, M., Roy, A., Marfell-Jones, M., Irurtia, A., 2018. Assessing subcutaneous adipose tissue by simple and portable field instruments: Skinfolds versus Amode ultrasound measurements. PLoS ONE 13(11), 1-13. e0205226.

Potter, P.A., Perry, A.G., Stockert, P.A., Hall, A.M., 2017. Fundamentals of Nursing. In. Medication Administration, 9th ed. St Louis: Elsevier Inc; p.647-49.

Pozzuoli, G.M., Laudato, M., Barone, M., Crisci, F., Pozzuoli, B., 2018. Errors in insulin treatment management and risk of lipohypertrophy. Acta Diabetologica, 55(1), 67-73.

Spollett, G., Edelman, S.V., Mehner, P., Walter, C., Penfornis, A., 2016. Improvement of insulin injection technique: examination of current issues and recommendations. Diabetes Educator 42, 379-94.
Torun, S., Mutluay, Ş.D., 2017. Applicability of calf subcutaneous tissue to subcutaneous injection in young adults. Applied Nursing Research 34, 66-69.

Tubiana Rufi, N., 2009. Short needles reduces the risk of intramuscular injections in children with type 1 diabeets. Diabeets Care 22, 1621-1625.

Turan, N., Aydın, G.Ö., Kaya, N., 2019. Subkütan Enjeksiyon Uygulamasında Güncel Yaklaşımlar. Sağlık Bilimleri ve Meslekleri Dergisi 6(2), 406-411.

Wagner, D.R., Cain, D.L., Clark, N.W., 2016. Validity and reliability of a-mode ultrasound for body composition assessment of NCAA division I athletes. PLoS One 11, 1-12.

Zijlstra, E., Jahnke, J., Fischer, A., Kapitza, C., Forst, T., 2018. Impact of injection speed, volume, and site on pain sensation. Journal of Diabetes Science and Technology 12(1), 163-168. 